\title{
Athletic taping and its implications in sports
}

\author{
Gurpreet Singh \\ Lecturer in Physical Education: J\&K Govt. INDIA \\ Neeraj Sharma: PET: J\&K Govt. INDIA
}

\begin{abstract}
Athletic taping is an adjunct mechanism adopted as a preventive measure of injuries or post-injury rehabilitation and prophylaxis. The tape is chosen properly so that it could be able to properly strap the body parts, e.g., ankle, wrist, finger, etc. There are certain principles, guidelines, rules and regulations based on which taping has to be done. Besides injury prevention, taping is also used in sports as conservative management of pain, biomechanical effects, effects on balance, posture and neuromuscular system, rehabilitation. Taping has been found to be effective in cases of ankle, foot, hand and wrist injuries as well as appeared to be more valuable in rehabilitation than in prevention of knee and ankle injury. A modern and new approach of taping is kinesiology tape which provides athletes with a solution for working through minor injuries and recovering faster from major injuries and has also been found to be an ideal modality for use in chiropractice settings. It also helps in enhancement of endurance capacity and even performance level in certain cases. Contradictory opinions exist among scientists regarding the advantages and disadvantages of application of taping in sports. Nonetheless Athletic Taping is recommended with certain precautions for the benefit of the sportspersons and athletic performance.
\end{abstract}

Keywords: kinesiotaping, injury, chiropractice, athletes, sport performance.

\section{INTRODUCTION}

Athletic taping is a temporary technique or an adjunct mechanism adopted as a measure of post-injury rehabilitation (Birrer \& Poole, 2004). It is mainly used as a preventive measure by athletes to protect an existing injury. The goals of the taping in sports are to restrict motion of injured joint(s), compress soft tissues to prevent swelling, support to the anatomical structure involved in the injury, serve as a splint or to secure a splint, secure the dressing and/or bandages, protect the injured part from re-injury and to protect the injured part while the healing process is under progress (Birrer \& Poole, 2004).

Therefore, the taping is mainly procured as one of the means of rehabilitation and prophylaxis in cases of support and stability, immediate first aid, securing a pad or brace, preventing injury, restricting the angle of pull and psychological assistance (Birrer \& Poole, 2004).

Athletic Taping has been in the fore-front for a long time. It plays an important role in coping up with post injury conditions of an athlete and also performing in the field even before completing the rehabilitative recovery from injury. Literatures suggest that taping serves as a measure of "post-injury rehabilitation" and yet there has still been others who point out on the disadvantages of taping in reducing performance and skill (Aminaka \& Gribble, 2005; Nyland et al., 2002; Ernst et al., 1999; Inklaar, 1994; Warme \& Brooks, 2000; Parkkari, 2002). Although it is such a common technique, yet complete guide to the principles and techniques involved in taping, its advantages, types, disadvantages, etc. are rare to be found. This article nonetheless serves the purpose of providing a suitable guide about the basics of Athletic Taping.

The McConnell method of patellar taping has been a popular practice among athletic trainers and other health care professionals when treating patients with PFPS. However, the clinical evidence for the success of this intervention is still unclear. An insufficient number of randomized controlled trials, inconsistency of tape application techniques, and variance in measurement of specific outcome variables limit the strength of clinical efficacy and evidence (Aminaka \& Gribble, 2005). 


\section{PRINCIPLES OF TAPING:}

Athletic taping is based on certain criteria or set rules, regulations and guidelines which form the major "principles" based on which the experts carry out the process of taping on the injured part of the sports person. General principle also includes few criteria which practitioners should consider - skin preparation, functional position of the body part to be taped, body mechanics of the practitioner, $t$ ape application and removal of the tape post activity. Skin preparations that should be carried out before taping includes removal of hair, cleaning of skin, addressing of any lesions with necessary consultation, using adherents and lubricants, ander wraps, under pads, etc. (Zetaruk, 2000). The major principles which are to be followed are (Garret et al., 2001; Gissane et al., 2001):

- Placing the athlete in an appropriate position.

- Appropriate selection of:

$>$ A comfortable table height and position that is appropriate for the health care provider to minimize strain and fatigue.

- Application of tape:

$>$ Type and width of the tape.

$>$ To a dry and clean area and at body temperature. o Immediately after cryotherapy or hydrotherapy is to be prevented.

$>$ Immediately after cryotherapy or hydrotherapy is to be prevented.

$>$ Taping should be:

$>$ Prevented at the site of perspiration.

$>$ Applied directly on skin or on under-wrap.

$>$ Done on skin with the tape adherent to prevent slippage.

- Areas subjected to friction blisters should be covered with protective pads or under-wraps.

- While applying tape, the following should be kept in mind:

$>$ It should be firm, yet smooth and wrinkle free

$>$ Here should not be impairment of normal circulation, normal movement of muscles and tendons present underneath the tape.

$>$ Avoid pressure on bony prominences.

$>$ Any tingling, numbness, decreased tactile sensations or impaired distal venous return should be monitored and taken care of immediately, if noted.

- The tape is to be broken or torn in an extended or stretched fashion to avoid folded edges

- Removal of tape should be done following the proper methods by using tape cutters and specially designed scissors

- The skin has to be cleaned adequately of the tape residue

- Any blisters or skin abrasions, if noted, should be taken care of immediately

\section{TYPES OF TAPE USED IN SPORTSPERSONS}

A tape should be chosen properly so as to be able to strap the given body part properly. It should be of the proper size.

Tape is graded on the basis of the following characteristics (Birrer \& Poole, 2004):

- Number of vertical (warp) and horizontal (woof) threads per square inch.

- Tensile strength.

- Composition.

$>$ Bleached or unbleached cotton. o Cotton plus synthetic fibre.

$>$ All synthetic fibre.

- Adhesive mass (stickiness).

The thread count varies between 120 and 150 per sq. inch. Higher thread count implies higher tensile strength, overall higher quality, better adhesive, easier to unwound, long lasting and costlier (Birrer \& Poole, 2004). Tensile strength increases on folding edge of the tape whereas bleaching and colouring lowers it. 


\section{COMMON TAPING TECHNIQUES}

Taping can be done in various regions of the body as and when required. Table 1 illustrated the uses of different taping techniques along with the common cases of injury in which they are used and the corresponding needed materials.

Significance of taping in sports

- Injury Prevention:

Taping is mainly used to provide assistance to the athlete for the return to activity after a minor injury (Cartwright \& Pitney, 2003). Proper application of the tape is generally able to provide stability and support to the injured structure, thus helping the athlete to return to the sport before the area has returned to pre-injury status. Taping has been familiarized as one of the major procedure of prevention strategies to reduce injury in collision sports by reduction in the possibility of extrinsic factors like contact with equipment or another participant (Parkkari et al., 2001; Marshall et al., 2001; Gissane et al., 2001; Engstrom \& Renstrom, 1998). Overuse injury of the wrists and ankles, especially in gymnastics can also be prevented (Chomiak et al., 2000). Severity of many injuries can be reduced to some extent by taping (Inklaar, 1994). Taping may prove to be superior to rigid and semi-rigid bracing in injury prevention (Zetaruk, 2000). Community amateur and most professional athletic events most frequently use prophylactic taping (Robbins \& Waked, 1998). It has also been proposed that taping reduces occurrence of injury and its intensity in most sporting activities (Butterwick et al., 1996; Bahr et al., 1994

- Conservative management:

Appropriate application of tape has been found to reduce the symptoms of medial tibial stress syndrome or shin splint (Specchiulli \& Cofano, 2001). In most patients non-operative treatments including patellafemoral taping and bracing has been considered effective (Agnew, 1993). Taping has been found to be effective in combating turf-toe injuries (Ugalde \& Batt, 2001). Taping has been referred for a condition "sand toe", a condition similar to turf-toe along with certain other precautions (Powers et al., 1997). Nonoperative management in certain wrist injuries in cases of alpine skiing includes taping (Frey et al., 1996).

- Biomechanical effects of taping:

Taping has significant advantages in assisting the patient in maintaining normal biomechanics during participation (Palmer \& Lane-Larsen, 1994). Ankle taping has been found to decelerate inversion velocity significantly and facilitate a protective neuromuscular response (Ernst et al., 1999). Taping improves force attenuation in lower extremity during running by shifting peak force to forefoot and hence acting synergistically in weight bearing (Baquie, 2002; Nyland et al., 2002).

- Role in Pain Management:

Taping plays a significant role in reduction of pain form physical activity. Irritated inflamed neural tissue can be mechanically uploaded by taping along the nerve tract, thus shortening the inflamed region and reducing the pain (Heidt et al., 1996; McConnell, 2002). Taping has been found to improve resting scapular position (Baker \& Juhn, 2000). Often before considering surgical alternatives as in case of patella-femoral pain syndrome, taping is considered to be a better method (McConnell, 2000).

- Taping has been found to enhance proprioception and position sense at the ankle (Alt et al., 1999; Refshauge et al., 2000; Simoneau et al., 1997).

- Taping is a preventive strategy during lower extremity rehabilitation by minimizing foot and ankle injuries especially during functional return activities (Loudon et al., 1998).

Table 1. Use of different taping techniques with the corresponding needed materials along with the common cases of injury.

\begin{tabular}{|l|l|l|l|}
\hline $\begin{array}{l}\text { Name of } \\
\text { technique }\end{array}$ & $\begin{array}{l}\text { Common injuries } \\
\text { where used }\end{array}$ & Materials needed & Use of techniques \\
\hline $\begin{array}{l}\text { Ankle } \\
\text { Taping }\end{array}$ & $\begin{array}{l}\text { Inversion sprains } \\
\text { Rolled Ankle ] }\end{array}$ & $\begin{array}{l}\text { Heel and lace pads,pre- } \\
\text { wraps,Zinc oxide }\end{array}$ & $\begin{array}{l}\text { Support and stabilization of the } \\
\text { ankle joint for inversion sprains }\end{array}$ \\
\hline
\end{tabular}




\begin{tabular}{|c|c|c|c|}
\hline $\begin{array}{l}\text { Wrist } \\
\text { Taping }\end{array}$ & $\begin{array}{l}\text { Fall on outstretched } \\
\text { hand, contusion, chronic } \\
\text { overuse injuries }\end{array}$ & Zinc oxide, tufskin & $\begin{array}{l}\text { Support, limiting movement at } \\
\text { the radiocarpal and midcarpal } \\
\text { joints. }\end{array}$ \\
\hline $\begin{array}{l}\text { Thumbs } \\
\text { Spica }\end{array}$ & $\begin{array}{l}\text { Jammed thumb [ Ball ] } \\
\text { fall on hand [ Hyper } \\
\text { flexion/extension ] }\end{array}$ & Zinc oxide, tufskin,ultralite & $\begin{array}{l}\text { Support and restriction of ROM } \\
\text { in the } \mathrm{MCP} \text { joint of the first ray } \\
{[\text { Thumb ] }}\end{array}$ \\
\hline $\begin{array}{l}\text { Turf Toe } \\
\text { Taping }\end{array}$ & $\begin{array}{l}\text { Sudden stop, the foot } \\
\text { slides forward in the } \\
\text { shoes }\end{array}$ & Zinc oxide, tufskin & $\begin{array}{l}\text { Support to the ligaments of the } \\
\text { MTP joints and protection to } \\
\text { the articular surfaces }\end{array}$ \\
\hline $\begin{array}{l}\text { Finger } \\
\text { Taping }\end{array}$ & $\begin{array}{l}\text { Jammed finger, sprains, } \\
\text { return to sports post- }\end{array}$ & Zinc oxide & $\begin{array}{l}\text { Support and prevention of re- } \\
\text { injury of MCP and IP joints }\end{array}$ \\
\hline $\begin{array}{l}\text { Achiles } \\
\text { Tendon } \\
\text { Taping }\end{array}$ & $\begin{array}{l}\text { Acute : sprinting, } \\
\text { jumping, chronic } \\
\text { tendonitis, chronic } \\
\text { strains }\end{array}$ & $\begin{array}{l}\text { Elastic tape, turfskin, Zinc } \\
\text { oxide, heel and lace pads }\end{array}$ & $\begin{array}{l}\text { Limiting range of dorsiflexion } \\
\text { and decreasing tension on the } \\
\text { achiles tendon. }\end{array}$ \\
\hline $\begin{array}{l}\text { Hamstring } \\
\text { tens or } \\
\text { wrap }\end{array}$ & $\begin{array}{l}\text { Hamstring strains and } \\
\text { contusion }\end{array}$ & $\begin{array}{l}\text { Double } 6 \text { tensor ultrlite } \\
\text { zinc oxide, foam pressure } \\
\text { pad }\end{array}$ & $\begin{array}{l}\text { Support to the hamstring and } \\
\text { prevent re- injury, }\end{array}$ \\
\hline Hip spica & $\begin{array}{l}\text { Overuse of hip flexor } \\
\text { muscles, muscle strains }\end{array}$ & $\begin{array}{l}\text { Double } 6 \text { tensor ultrlite } \\
\text { zinc oxide, foam pressure } \\
\text { pad }\end{array}$ & $\begin{array}{l}\text { Limiting range of hip } \\
\text { extension, support to hip flexor } \\
\text { muscle and prevention of injury }\end{array}$ \\
\hline
\end{tabular}

\section{EFFICACY OR EFFECTIVENESS OF TAPING}

Taping has been found to be effective in cases of ankle, foot, hand and wrist injuries as well as appeared to be more valuable in rehabilitation than in prevention of knee and ankle injuries. After a brief duration (2-3- minutes) of motion, the stiffness exerted due to taping gradually decreases (Wojtys \& Huston, 2001). It extends an enhanced mechanical support and proprioception to the ankle without any negative effects on body posture and equilibrium (Mascaro \& Swanson, 1994). Best performance of taping is limited to dorsiflexion (Rooks, 1997; Cordova et al., 2000). Adhesive tape has been found to be superior to cloth bandaging for supporting unstable ankles (Moss et al., 1993).

Silicone rubber is effective for fabricating splints to protect stable injuries to hand and wrist (Canelon, 1995; Jerosch et al., 1996). Taping has been found to be a protective and rehabilitative technique for digital injuries when combined with modified exercise schedules and stretching (Warme \& Brooks, 2000) However, based on the current literatures, taping is a useful tool to the clinician in treating patellofemoral pain syndrome and does not seem to exacerbate the symptoms. Although the exact mechanism of the disease is often not completely known, but regardless of the choice of therapeutic intervention, it is important to thoroughly understand or speculate the mechanisms and causes of the patient's patellofemoral pain (Aminaka \& Gribble, 2005).

Kinesiology taping: a newer and modern approach of popular taping method Kinesiology tape provides athletes with a solution for working through minor injuries and recovering faster from major injuries. In addition, it can enhance endurance and performance during training sessions and matches, as well as accelerate recovery after intense exercise

Unlike traditional athletic tape that is tight and restrictive, kinesiotape provides support without limiting range of motion. It is water resistant and breathable, and can be worn for up to 5 days, even through intense exercise, showering or swimming

What makes kinesiology taping such a great fit for Airrosti? 
- The improved lymphatic drainage will help minimize swelling and bruising of the treated tissues.

- The enhanced blood flow to the injured tissues supports more rapid healing.

- The lifting action of the tape on the skin decreases pressure on pain receptors, making both the injury and the effects of the treatment less painful.

- Kinesiology tape provides support for injured muscles or joints while still allowing a full, healthy range of movement, an important component in rehab

Kinesiology taping is an ideal modality for use in chiropractic settings that interplays between the body's neurological system, muscular system and its structural and fascial frameworks. Effective kinesiology taping involves all of these systems, allowing chiropractors to quickly grasp the principles and techniques for applying kinesiology tape.

\section{DISADVANTAGES OF TAPING}

Athletic taping has been considered by some scientists of having some disadvantages.

- Though not reliably proven, yet it is speculated that taping decreases the muscular strength of the involved area and leads to less electro-myographic activity and reduction in muscle action (Hopper et al., 1999).

- The athletes have a tendency of developing psychological dependence on the external support (Birrer and Poole, 2004).

- Incorrect application of tape by unskilled persons might predispose the athlete to injury or cause severe blisters (Gissane et al., 2001).

- Taping is comparatively more expensive than other injury prevention techniques like bracing etc. (Birrer and Poole, 2004).

\section{PRECAUTIONS TO TAPING}

Taping should be done under strict guidance of an expert and should not be applied under the following circumstances:

- Injuries requiring more than tape can provide

- When taping excessively restricts the ROM of a joint predisposing the athlete to further injury Inflammation

- Taping of lacerations, abrasions, blisters

- Allergic reactions to tape or adherence and bandage

\section{CONCLUSION}

Athletic Taping has been found to have both advantages and certain disadvantages. According to some scientists it is more of a boon to the athletes as a part of their post-injury rehabilitation and to others it is a mere burden which reduces the capability and intensity of performance of the athlete. Nonetheless it is widely famous and common in use among majority of athletes for various of its advantages as stated earlier and it still remains a question as to whether it is a boon or a burden.

\section{REFERENCES}

1. ALT W, LOHRER H, GOLLHOFER A. Functional Properties of additional ankle taping: neuromuscular and mechanical effects before and after exercise. Foot Ankle Int. 1999; 20:238245.

2. AGNEW PS. Taping of the foot and ankle for Korean karate. J Am Podiatr Med Assoc. 1993; 83:534-6.

3. AMINAKA N, GRIBBLE PA. A systemic review of the effects of therapeutic taping on patellofemoral pain syndrome. J Athletic Train. 2005; 40:341-351.

4. BAHR R, KARLSEN R, LIAN O, OVREBO RB. Incidence and Mechanisms of acute ankle inversion injuries in volley ball. Am J Sports Med. 1994; 22:595-600.]

5. BAKER MM, JUHN MS. Patellofemoral pain syndrome in the female athlete. Clin Sports Med. 2000; 19:315-329. doi:10.1016/S0278-5919(05)70206-4 
6. BAQUIE P. Lower Limb Taping. Aust Fam Physician. 2002; 31:451-452.

7. BIRRER RB, POOLE B. General Principles, Specifics for the Ankle, Taping of Sports Injuries: Review of a Basic Skill. J Musculoskel Med. 2004; 21:197-211.]

8. BUTTERWICK DJ, NELSON DS, LAFAVE MR, MEEUWISSE WH. Epidemiological analysis of injury in one year of Canadian professional rodeo. Clin J Sports Med. 2004; 6:171177. doi:10.1097/00042752-199607000-00006

9. CANELON MF. Silicone rubber splinting for athletic hand and wrist injuries. J Hand Ther. 1995; 8:252-257. doi:10.1016/S0894-1130(12)80117-7

10. CARTWRIGHT LA, PITNEY WA. Athletic Training for Student Assistants. Human Kinetics, USA; 1999

11. CHOMIAK J, JUNGE A, PETERSON L, DVORAK J. Severe Injuries in Football players. Influencing Factors. Am J Sports Med. 2000; 28:S58-S68.

12. CORDOVA ML, INGERSOLL CD, LEBLANC MJ. Influence of ankle support on joint range of motion before and after exercise: a meta-analysis. J Orthop Sports Phys Ther. 2000; 30(4): 170177.

13. ENGSTROM BK, RENSTROM PA. How can injuries be prevented in the World cup Soccer athlete? Clin Sports Med. 1998; 17:755-768.

14. ERNST GP, KAWAGUCHI J, SALIBA E. Effect of patellar taping on knee kinetics of patients with patellofemoral pain syndrome. J Orthop Sports Phys Ther. 1999; 29:661.

15. FERGUSON AB. The Case against ankle Taping. Am J Sports Med. 1973; 1:46-47. doi:10.1177/036354657300100213

16. FREY C, ANDERSEN GD, FEDER KS. Plantarflexion injury to the metatarsophalangeal joint ("sand toe"). Foot Ankle Int. 1996; 17:576-581

17. GARRETT WE, KIRKENDALL DT, SQUIRE DL. Principles and practice of primary care sports medicine. Lippincott Williams and Wilkins: Philadelphia, 2001. [Back to text]

18. GISSANE C, WHITE J, KERR K, JENNINGS D. An Operational Model to Investigate contact Sports Injuries. Med Sci Sports Exerc. 2001; 3:1999-2003. doi:10.1097/0000576820011200000004

19. HEIDT RS JR, DORMER SG, CAWLEY PW, SCRANTON PE JR, LOSSE G, HOWARD M. Differences in friction and torsional resistance in athletic shoe-surface interfaces. Am J Sports Med. 1996; 24:834-842. doi:10.1177/036354659602400621

20. INKLAAR H. Soccer injuries II. Aetiology and Prevention. Sports Med. 1994; 18:81-93. doi:10.2165/00007256-199418020-00002 JEROSCH J, THORWESTERN L, BORK H, BISCHOF M. Is prophylactic bracing of the ankle cost effective? Orthoped. 1996; 19:405-414. LOUDON JK, GOIST HL, LOUDON KL. Genu recurvatum syndrome. J Orthop Sports Phys Ther. 1998; 27:361-367.

21. MARSHALL SW, WALLER AE, LOOMIS DP, FEEHAN M, CHALMERS DJ, BIRD YN, et al. Use of Protective equipment in a Cohort of Rugby players. Med Sci Sports Exerc. 2001; 33:2131-2138. doi:10.1097/00005768-200112000-00024 [Back to text]

22. MASCARO TB, SWANSON LE. Rehabilitation of the foot and ankle. Orthop Clin North Am. 1994; 25:147-160.

23. MCCONNELL J. A novel approach to pain relief: pre-therapeutic exercise. J Sci Med Sport. 2000; 3:325. doi:10.1016/S1440-2440(00)80041-9

24. MCCONNELL J. Racalcitrant chronic low back and leg pain--a new theory and different approach to management. Man Ther. 2002; 7:183-192. doi:10.1054/math.2002.0478

25. MOSS CL, GORTON B, DETERS S. A comparison of prescribed rigid orthotic devices and athletic taping support used to modify pronation in runners. J Sport Rehabil. 1993; 2:179-188

26. NYLAND JA, ULLERY LR, CABORN DN. Medical patellar taping changes the peak plantar force location and timing of female basketball players. Gait Posture. 2002; 15:146-152. doi: 10.1016/S0966-6362(01)00145-X

27. PALMER DH, LANE-LARSEN CL. Helicopter skiing wrist injuries. A case report of "bugaboo forearm”. Am J Sports Med. 1994; 22:148-149. doi:10.1177/036354659402200124 ] 
28. PARKKARI J, KUJALA UM, KANNUS P. Is it possible to prevent Sports Injuries? Review of Controlled Clinical Trials and Recommendations for Future Work. Sports Med. 2002; 31:985995.

29. POWERS CM, LANDEL R, SOSNICK T, KIRBY J, MENGEL K, CHENEY A, ET AL. The effects of patellar taping on stride characteristics and joint motion in subjects with patellar pain. J Orthop Sports Phys Ther. 1997; 26:286-291.

30. REFSHAUGE KM, KILBREATHE SL, RAYMOND J. The effect of recurrent ankle inversion sprain and taping on proprioception at the ankle. Med Sci Sport Exerc. 2000; 32:10.

31. ROBBINS S, WAKED E. Factors associated with ankle injuries. Preventive measures. Sports Med. 1998; 25:63-72. doi:10.2165/00007256-199825010-00005 [Back to text]

32. ROOKS MD. Rock climbing injuries. Sports Med. 1997; 23:261-270. doi:10.2165/00007256199723040-00005

33. SIMONEAU GG, DEGNER RM, KRAMPER CA, KITTLESON KH. Changes in ankle joint proprioception resulting from strips of athletic tape applied over the skin. J Athletic Train. 1997; 32:141

34. SPECCHIULLI F, COFANO RE. A comparison of surgical and conservative treatment in ankle ligament tears. Orthoped. 2001; 24:686-688. [Abstract]

35. UGALDE V, BATT ME. Shin splints: current theories and treatment. Crit Rev Phys Rehabil Med. 2001; 13:217-253.

36. WARME WJ, BROOKS D. The effect of circumferential taping on flexor tendon pulley failure in rock climbers. Am J Sports Med. 2000; 28:674-678. [Abstract] [Back to text] 39. WOJTYS EM, HUSTON LJ. “ Customer-fit" versus "off-the-shelf” ACL functional braces. Am J Knee Surg. 2001; 14:157-162.

37. WRIGHT KE, WHITEHILL WR. The Comprehensive Manual of Taping and Wrapping Techniques, Cramer Products Inc. USA;1996

38. ZETARUK MN. The Young Gymnast. Clin Sports Med. 2000; 19:757-780. doi:10.1016/S02785919 